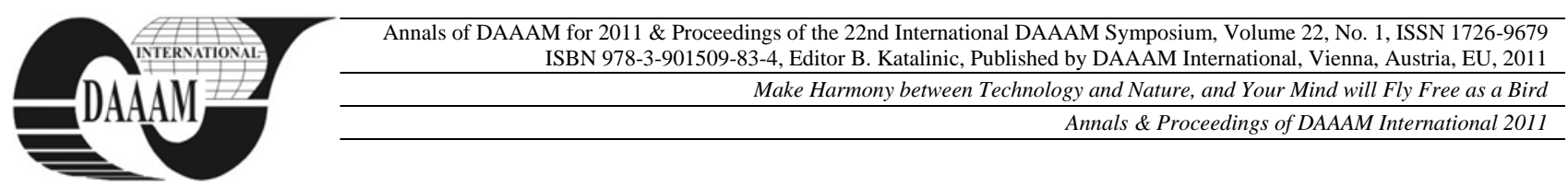

\title{
HOW THE ECONOMIC CRISIS AFFECTS THE COMPANIES MANAGEMENT
}

\author{
DAVID, O[ana]; OSICEANU, S[anda] \& DAVID, M[ihaela] F[lorentina]
}

\begin{abstract}
The current economic crisis has had consequences for all sectors of the economy and has influenced national economies at a global level. Therefore, the companies were obliged to adjust to these new conditions in order to keep themselves on the market. The paper presents how the activity of the managers and the entrepreneurs has changed during the crisis and how they are trying to survive on the market. The size of the companies, the ability and experience of these leaders are important factors with decisive roles both in this process of survival as well as in deriving the necessary revenues that will allow them to overcome this difficult period.
\end{abstract}

Key words: manager, crisis, entrepreneur, economy, continuing education, human resources

\section{INTRODUCTION}

In the nowadays context of the global economic development, the human resources represent the essential element in the competition, both nationally and internationally. Statistics show that the European countries have a particular interest in the continuous education of the human resources, mainly because of the specific discrepancies among these resources in the European Union member states. Until now, the investments made into education and human resources have proved to be the most efficient methods of the long run development in a society.

The lifelong learning must help with solving some of the issues that the contemporary society needs to deal with. As a result, the education systems have to function in dependence with the needs of the society, while having a certain stability and continuity that will provide long-term efficiency.

,There are no crisis managers, just good managers and weak managers' - is one of the current clichés regarding human resources. Prior to that, the difference was represented by the level of the profit being derived and now, the difference is from profit to loss. This is the reason why the managers who are able to constantly obtain profit may have the luxury of getting a higher income. During this time of crisis, some companies have tried to adopt an appropriate management to match their present situation, but not all of them have succeeded it. The ones that failed were ousted from the market while the rest should learn from their lessons.

\section{PAPER DATA}

The present economic crisis originates in the middle of the 90 's, in the United States of America. It did extend worldwide in the year of 2008, with harmful macro-economic and social consequences. The starting point was represented by the management problem of the long-term capital in the USA, followed by the drastic decrease of the interest rate and the attempt of the Federal Reserve System of USA to save the financially challenged institutions, climaxing with the lowering of the federal funds rate at the end of 2008. The responses of Europe towards the crisis were heard rather late and they seemed not to be coordinated at all times. At first, the danger of the financial crisis has been sugarcoated by most decisional factors in the European countries. The starting of the financial crisis in Europe has revealed the large number of weak points of the European financial institutions, which are not at all different, but quite similar to their counterparts in the USA. The collapse of a bank or of an investments fund will likely trigger a huge chain reaction - if we remember the experience at the end of 2008, when Lehman Brothers went bankrupt (Dabrowski, 2010).

The economic crisis has also brought about a series of changes on the labor market. The importance of training the human resources for this emergent market is supported by the necessity to react to quick changes, to require new skills. The employers seem to favor the graduates with a general training (foreign languages, computers, general management), as they want to instruct the new employees at a local level, in dependence with the needs that are specific to the employment place. In a market economy that is in a constant change and renewal, the workforce must be prepared to be flexible, since the total or partial modifications of the employment places take place quite often. A large part of the economy adjusts itself to the crisis and this process involves, theoretically, massive professional retraining. On a practical level, it means that people are supposed to adapt to areas that are new to them, which they do not have a very good idea about (Marinas, 2010).

During time of crisis, many companies are making attempts to lower their expenses to a minimum, but at the same time they are doing their best to stay on the market. A substantial number of them reached the conclusion that a smaller number of employees will do the trick for them. However, this solution is not a feasible one, and proves the existence of a critical management. Overloading the existing workers with further job tasks will surely bring on more stress and quick exhaustion - in a free translation, it means a lower productivity of the people at their employment place, on both medium- and long-term.

The crisis periods are the one providing the opportunity to any company to prove that the management really works and knows what measures to adopt in order to get across this stage, with minimum losses. These measures will allow the motivation of the employees, even though they are left without certain benefits. This window of time brings high expenses for most of the companies, from the newly opened, on a minimum share capital, to the large multinational companies, older on the market. Each of such companies has a surging interest in savings, which is the costs planning and optimization.

A string of countries have taken measures to lower the wage-related expenses, such as: reduction of wages, unpaid leaves, layoffs. These measures have also negative effects, i.e. the smaller number of employees will affect the company's productivity, lowering the wages will lead to the employee's dissatisfaction and, implicitly, to their lack of efficiency (Manole, 2006). The outcome of these remuneration lowering during the time of crisis was a drastically reduction of consumption, as people were oriented more towards savings by giving up, postponing the acquisition of luxury products and 
services or any products and services that did not strictly refer to a decent existence. In this context, we could observe behaviors that are completely different among various companies. These dissimilarities may derive from the history of company, the patrimony and their economic status, as well as because of the crisis effects.

The companies with a stable management (no changes for the last 8 years) are characterized by a low stress perception and a greater satisfaction of the employees at their work place. (Iatagan et al., 2010). People working here are oriented towards strategies that involve social support and solving problems, focusing to their relations with other people.

People working in companies where management is changing (a change of the company's administration methods during the last 3 years) perceive stress at a higher level and have less satisfaction at their employment place, focusing more on challenging strategies. The managers in the stable companies are more capable in their attempt to buffer the crisis effects, to lower the stress perception of their employees and to maintain a higher satisfaction level of them via promoting certain strategies that involves common values and objectives.

The companies found in a changing process are more vulnerable to crisis and experiment challenge-based strategies, which involves higher energy consumption and a bigger creative effort during the decision-taking process. For these companies, a need for consolidating the feeling of belonging and trust of the people working there is required (Togni et al., 2010). The managers will sense a bigger pressure of the company's internal environment, as they are more concentrated on the others, on the social support that they may provide. They are rather interested on the short-term objectives.

As for the activity of the entrepreneurs, the authorities have to make their life easier, by the measures they take during crisis time. For example, some countries have helped the private sector by bringing forth better conditions in terms of the company setting-up, exempt from paying taxes during their first years, tax relief, hence an encouragement for the consumption.

Entrepreneurship involves the implementation of certain groundbreaking ideas, triggering financial losses. This is why the entrepreneur is a person who will be willing to take challenges, to take risks, who brings pioneering ideas and puts them into practice, no matter how big the obstacles are in his way. The young entrepreneurs should concentrate upon the fields that require a quite small capital to start, i.e. services, as it is more affordable. Similarly, they should have better prices than the traditional suppliers, ,low cost' type. It is desirable that a young entrepreneur, without significant financial resources, go for an activity in the services area, firstly based on his work capital and his team's - these being the businesses where the financial resources are not among the mandatory prerequisites.

At present, besides the financial aid granted by the government via adopted anti-crisis measures, entrepreneurs should do the following to focus on the crisis management; to know themselves very well and learn something every day; to look forward, foreseeing the events; to have a good training in terms of human resources and a project management.

The best entrepreneurs are the ones who make it through a crisis time. There are big chances that we will have a new generation of better entrepreneurs after this period - not only because there would be new entrepreneurs in full crisis, but whoever comes out of this trial will be stronger and more valuable (http://www.manager.ro).

The crisis-type entrepreneur is very open to changes, flexible, and not that much interested to an immediate cashing, as they are ready to risk. During crisis, it is easier for entrepreneurs to build a good work team, as the number of skilled candidates, available on the labor market, is higher, due to the economic crisis and to their low financial demands. Another advantage for the crisis entrepreneur is that it gets easier to motivate the valuable people.
The analysis of the differences between entrepreneurs and managers shows a high level of complementarity among the professional profiles. During crisis, entrepreneurs feel a higher stress as for the employment places and their responsibilities related to the company survival and development. The economic results are not essential objectives for them, since their strategies are oriented on solving the problems and having a positive attitude towards life.

The feeling of being challenged while facing the crisis is a factor that motivates the entrepreneur's behavior, which presupposes optimism for the future, as they are trying to understand the real issues that they encounter on a daily basis. Generally speaking, the crisis has raised the awareness level among entrepreneurs and managers.

\section{CONCLUSION}

The crisis time has had the purpose to help with the sorting of the companies in the business environment. The more agile companies, the ones that had the ability to adjust themselves, have succeeded to come out unharmed; besides, some of them had a better market share, thanks to the smaller number of competitors. The difference between the ones that stayed and the ones that were out was made by the professionalism level of the management.

The stable companies have a greater ability to accommodate to the crisis; they feel less its effects, and, for the employment place, people are more confident and have the skill to participate in meeting certain objectives. The entrepreneurial role is defined by a positive attitude, while the function of the managers is of a relational mediation. Instead, the companies pending changes have assumed individualist strategies and have not joined the entire group, because challenge and creativity are the main elements of the strategies being adopted.

In all the companies, crisis has generated an escalation of relations between entrepreneurs and managers, which triggered the desire and need to re-think the relational dynamics. This thing may occur only by the strengthening of the stable companies, as well by building a feeling of belonging and trust in the companies going through changes, which are greatly affected by crisis.

The financial crisis is just a test for the entrepreneurs, and time passing will bring new generations of them, better than the previous ones. As said earlier, the new generation is very likely to be much better, as going through crisis make them more enduring and steadier.

A better monitoring of the company's activity, lowering the costs and preparation for supporting the future development are and will be the top objectives for the company management, with the explicit purpose of beating the crisis.

\section{REFERENCES}

Togni, M.; Cubico, S.; Favretto, G. (2010). Owners and managers in an economic crisis: how to exploit the differences, Procedia - Social and Behavioral Sciences, no.5, pp.1312-1316

Iatagan, M.; Dinu, C.; Stoica, A.M. (2010). Continuous training of human resources - a solution to crisis going out, Procedia - Social and Behavioral Sciences, no.2, pp.51395146

Dabrowski, M. (2010). The global financial crisis: Lessons for European integration, Economic Systems, no.34, pp.38-54

Manole, C. (2006). Human resource management in public administration, ASE Publishing

Marinas, C.V. (2010). Comparative human resource management, Economic Publishing House

*** Available from: http://www.manager.ro, Accessed: 201102-16 